\title{
Identification and characterization of anesthetic targets by mouse molecular genetics approaches
}

\section{L'identification et la caractérisation des cibles anesthésiques grâce à des approches fondées sur la génétique moléculaire chez la souris}

\author{
Berthold Drexler, MD • Bernd Antkowiak, PhD • \\ Elif Engin, PhD • Uwe Rudolph, MD \\ Received: 28 May 2010/Accepted: 26 October 2010/Published online: 21 December 2010 \\ (C) Canadian Anesthesiologists' Society 2010
}

\begin{abstract}
Purpose It is now generally accepted that proteins are the primary targets of general anesthetics. However, the demonstration that the activity of a protein is altered by general anesthetics at clinically relevant concentrations in vitro does not provide direct evidence that this target mediates pharmacological actions of general anesthetics. Here we report on advances that have been made in identifying the contribution of individual ligand-gated ion channels to defined anesthetic endpoints using molecular mouse genetics.

Principal findings Gamma-aminobutyric acid $(G A B A)_{A}$ receptor subtypes defined by the presence of the $\alpha 1, \alpha 4, \alpha 5$, $\beta 2$, and $\beta 3$ subunits and two-pore domain potassium channels (TASK-1, TASK-3, and TREK) have been discovered to mediate, at least in part, the hypnotic, immobilizing or amnestic actions of intravenous and volatile general anesthetics. Moreover, using tissues from genetically modified mice, specific functions of $G A B A_{A}$
\end{abstract}

This article is accompanied by an editorial. Please see Can J Anesth 2011; 58(2)

B. Drexler, MD · B. Antkowiak, PhD

Section of Experimental Anaesthesiology, Department of

Anaesthesiology, Eberhard-Karls-University, Tuebingen,

Germany

E. Engin, $\mathrm{PhD} \cdot \mathrm{U}$. Rudolph, MD (ه)

Laboratory of Genetic Neuropharmacology, MRC123A, McLean

Hospital, Harvard Medical School, Belmont, MA 02478, USA

e-mail: urudolph@mclean.harvard.edu

E. Engin, $\mathrm{PhD} \cdot \mathrm{U}$. Rudolph, MD

Department of Psychiatry, Harvard Medical School,

Belmont, MA, USA receptor subtypes in cortical and spinal neuronal networks were identified.

Conclusion Genetically modified mice have been very useful for research on mechanisms of anesthesia and have contributed to the functional identification of general anesthetic targets and of the role of these targets in neuronal networks.

\section{Résumé}

Objectif Aujourd'hui, il est universellement accepté que les protéines sont les cibles principales des anesthésiques généraux. Cependant, la démonstration que l'activité d'une protéine est modifiée in vitro par les anesthésiques généraux en concentrations pertinentes d'un point de vue clinique ne constitue pas une donnée probante directe prouvant que cette cible est le médiateur des actions pharmacologiques des anesthésiques généraux. Nous rapportons ici les progrès accomplis dans la détermination de la contribution des canaux ioniques individuels sensibles à un ligand à la définition des critères anesthésiques en utilisant la génétique moléculaire de la souris.

Constatations principales On a découvert que les sous-types de récepteurs $G A B A_{A}$ tels que définis par la présence des sous-unités $\alpha 1, \alpha 4, \alpha 5, \beta 2$, et $\beta 3$ et les canaux potassiques à deux domaines P (TASK-1, TASK-3 et TREK) médiaient au moins partiellement les actions hypnotiques, immobilisantes ou amnésiques des anesthésiques généraux intraveineux ou volatils. De plus, en analysant des tissus de souris génétiquement modifiées, nous avons pu identifier certaines fonctions spécifiques des sous-types de récepteurs $G A B A_{A}$ dans les réseaux neuronaux corticaux et rachidiens. Conclusion Les souris génétiquement modifiées ont été très utiles à la recherche sur les mécanismes de 
l'anesthésie et ont contribué à l'identification fonctionnelle des cibles des anesthésiques généraux et du rôle de ces cibles dans les réseaux neuronaux.

Based on the work by Meyer, Overton, and others, it has long been assumed that general anesthetics would exert their pharmacological effects by non-specifically perturbing the neuronal plasma membrane. However, it was later demonstrated in electrophysiological experiments that general anesthetics modulate the activity of a variety of targets, including ligand-gated ion channels, such as gamma-aminobutyric acid $(\mathrm{GABA})_{\mathrm{A}}$ receptors, $N$-methyl-Daspartate (NMDA) receptors, $\alpha$-amino-3-hydroxy-5methyl-4-isoxazole propionate (AMPA) receptors, and nicotinic acetylcholine receptors (for review $\mathrm{see}^{1}$ ). These studies have been performed in native tissues or in recombinant systems, the latter allowing the characterization of the sensitivity of defined receptor subtypes to general anesthetics. A potential limitation of the recombinant approach is that there is no guarantee that recombinant receptors behave in the same way as native receptors in a particular assay. In situ, neurotransmitter receptor subunits interact with other proteins (e.g., kinases, structural proteins) that may affect functional properties of the corresponding receptor. More importantly, the observation that a given anesthetic agent modulates the activity or directly activates or inhibits a receptor or ion channel target does not provide evidence that the target is essential for the anesthetic actions of the agent. If the target is essential, for which part of the pharmacological spectrum of the general anesthetic is the target responsible?

Genetically modified worms (C. elegans) and mice (the focus of this review) have been used to address the question of the functional significance of a specific target for the general anesthetic action of a given drug. A great variety of mouse molecular genetics techniques have evolved over the past two decades. Thus far, the two most important techniques with respect to research on anesthetic mechanisms are (1) targeted gene inactivation ("knockout"), and (2) targeted introduction of a point mutation ("knock-in").

In the targeted gene inactivation ("knockout") approach, a mutation (e.g., deletion of the entire gene, elimination of an essential exon, or insertion of a premature stop codon) is introduced into the gene of interest, which results in the abolishment of the expression of this gene. The basic idea is that if the gene product is essential for any action of a general anesthetic, this action would be missing in the mutant mice. Problems associated with the knockout approach include compensatory regulations that may involve upregulation of related receptor subunits or channels, which may be obscuring the effects of the gene knockout. A case in point are the $\mathrm{GABA}_{\mathrm{A}}$ receptor $\alpha 1$ subunit knockout mice. Although it is known from other approaches that $\alpha 1$ plays an important role in mediating the sedative action of benzodiazepines, ${ }^{2,3}$ the $\alpha 1$ knockout mice are even more sedated by diazepam than wild type mice, ${ }^{4}$ an outcome that may be explained by the upregulation of $\alpha 2$ and $\alpha 3$ subunits in regions where $\alpha 1$ is usually expressed, e.g. the cerebral cortex. ${ }^{5,6}$ Another interesting example for a compensatory upregulation is that $\alpha 6$ knockout mice exhibit upregulation of a two-pore domain potassium channel, TASK $-1^{7}$ in the cerebellum. In summary, a global knockout mouse may be thought of as having two modifications, i.e., the gene inactivation and the reaction of the animal to the gene inactivation. As a rough guide, if there is a phenotypic difference between knockout and wild type animals, this usually points to the inactivated gene being responsible for the difference; however, no phenotypic difference could mean that the inactivated gene is not involved in the response in question or that it is involved but the compensatory regulations are preserving the wild type phenotype. Sometimes knockout phenotypes may be severe, affecting multiple neuronal systems or the ability to respond in a particular test, and this may also make experiments difficult to interpret.

In contrast, knock-in mice carry more subtle mutations, e.g., single point mutations that block only specific functions of the protein in question. For example, histidine to arginine point mutations in the benzodiazepine binding site of $\mathrm{GABA}_{\mathrm{A}}$ receptor $\alpha$ subunits $\alpha 1, \alpha 2, \alpha 3$, and $\alpha 5$ resulted in the respective $\mathrm{GABA}_{\mathrm{A}}$ receptors becoming insensitive to modulation by diazepam, while the response to the physiological neurotransmitter GABA was preserved. ${ }^{8}$ Thus, the protein retains substantial functionality, and the expectation is that compensatory secondary changes would not occur or at least they would be substantially smaller than with knockout mice.

Both knockout and knock-in mutations have been generated in order to characterize the functional role of specific neurotransmitter receptors and other ion channels in the action of general anesthetics. Anesthetic endpoints used frequently in rodents are loss of hindlimb withdrawal reflex (or duration of loss of hindlimb withdrawal reflex) or the tail clamp withdrawal reflex (TCWR), which are indicative of immobility and surgical tolerance, or the loss of the righting reflex (LORR), which is used as proxy for unconsciousness (for more detailed description see references 9 and 10). Amnestic endpoints have been addressed using fear conditioning, ${ }^{1,12}$ the Morris water maze ${ }^{11}$ (a spatial memory task), and the passive avoidance paradigm. ${ }^{13}$ 


\section{Targets of general anesthetics}

\section{$\mathrm{GABA}_{\mathrm{A}}$ receptor}

The $\mathrm{GABA}_{\mathrm{A}}$ receptors are responsible for the majority of fast inhibitory neurotransmission in the central nervous system. The benzodiazepines, which are allosteric modulators of $\mathrm{GABA}_{\mathrm{A}}$ receptors containing the $\alpha 1, \alpha 2, \alpha 3$, or $\alpha 5$ subunits, are widely used as hypnotics, anxiolytics, muscle relaxants, and anticonvulsants. The $\mathrm{GABA}_{\mathrm{A}}$ receptors have long been shown to be modulated or even directly activated (although at concentrations that may not necessarily be clinically relevant) by general anesthetics, such as the intravenous anesthetics etomidate, propofol, and pentobarbital, and the volatile anesthetics like isoflurane, enflurane, and halothane (Fig. 1). The $\mathrm{GABA}_{\mathrm{A}}$ receptors have also been identified in non-neuronal tissues, e.g., in airway smooth muscle epithelium, where they increase $\beta$-adrenergic relaxation of human airway smooth muscle ${ }^{14}$ and are involved in mucus overproduction in asthma. ${ }^{15}$ This raises the possibility that such non-neuronal $\mathrm{GABA}_{\mathrm{A}}$ receptors are contributing to clinical effects of GABAergic drugs or to the phenotypes of global knockout mice.

\section{$\mathrm{GABA}_{\mathrm{A}}$ receptor knockout mice}

Early work with $\mathrm{GABA}_{\mathrm{A}}$ receptor knockout mouse models focused on the immobilizing and hypnotic endpoints. In mice lacking $\alpha 6$-containing $\mathrm{GABA}_{\mathrm{A}}$ receptors, it was reported that LORR was unaltered, in response to ethanol, enflurane, and halothane, as was the tail clamp response to enflurane. ${ }^{16}$ Lack of $\delta$-containing $\mathrm{GABA}_{\mathrm{A}}$ receptors increased the duration of LORR for the neurosteroids, alphaxalone and pregnanolone, but not for etomidate, propofol, midazolam, and ketamine; there was no change in duration of LORR or TCWR with halothane and enflurane. ${ }^{17}$ In mice lacking $\beta 3$-containing $\mathrm{GABA}_{\mathrm{A}}$ receptors, the duration of LORR was increased in response to midazolam and etomidate, but not in response to pentobarbital, ethanol, enflurane, and halothane; moreover, the immobilizing action of enflurane and halothane in the TCWR assay was decreased, although the effect size was limited. $^{18}$

Recently, knockout models have been employed to elucidate the amnestic actions of general anesthetics. Studies report $0.10-0.20 \%$ incidence of intraoperative awareness among patients, with certain risk groups showing even higher incidence rates. ${ }^{19,20}$ Given the large number of anesthesias performed, this frequency translates into approximately 60,000 patients per year in North America. $^{21}$ Thus, it is essential to understand the mechanisms underlying the amnestic effects of anesthetics.

Studies report that mice lacking the $\alpha 5$ subunit of the $\mathrm{GABA}_{\mathrm{A}}$ receptor exhibit better performance in hippocampal learning tasks compared with wild type mice. ${ }^{22,23}$ Electrophysiological studies using slices and organotypic cultures from the hippocampus have reported that GABAergic tonic inhibition and the slow component of the GABAergic inhibitory postsynaptic currents, $\operatorname{GABA}(\mathrm{A}$, slow) are enhanced by amnestic concentrations of different anesthetics, e.g., isoflurane, ${ }^{24}$ etomidate, ${ }^{11,25}$ and propofol. $^{26}$ Evidence suggests that these components of GABAergic inhibition are mediated to a great extent by the $\alpha 5$-containing

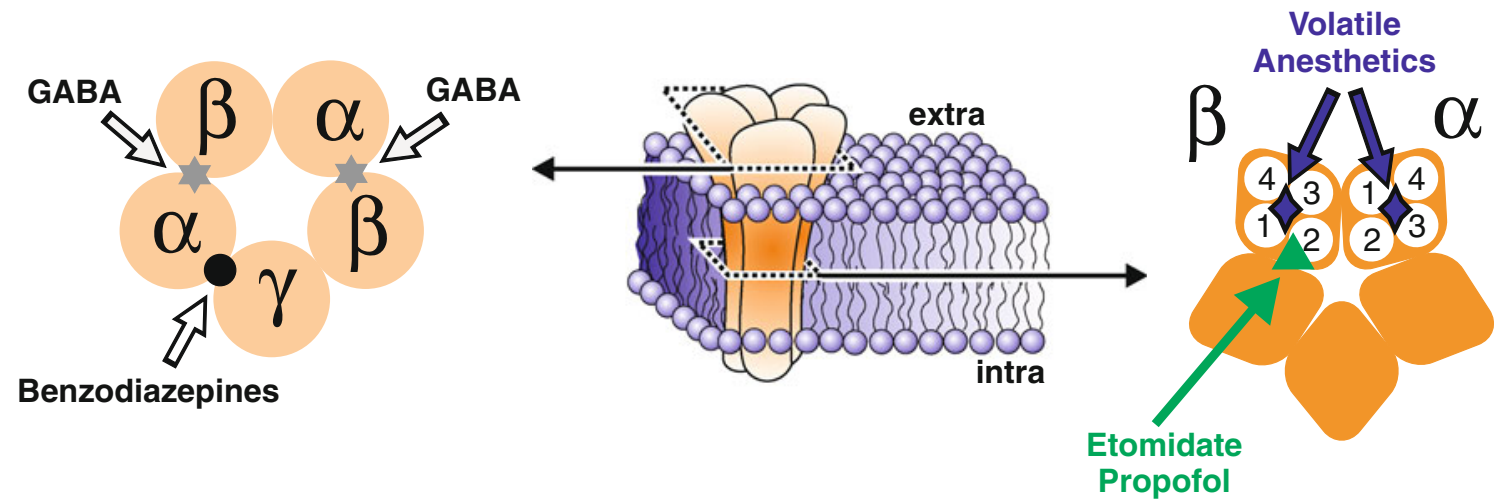

Fig. 1 Pentameric gamma-aminobutyric acid $(\mathrm{GABA})_{\mathrm{A}}$ receptors and binding sites for general anesthetics. The $\mathrm{GABA}_{\mathrm{A}}$ receptor is composed of five subunits surrounding the central channel pore. Central panel: Positioning of the $\mathrm{GABA}_{\mathrm{A}}$ receptor in the lipid bilayer. Left panel: Horizontal cross section of the $\mathrm{GABA}_{\mathrm{A}}$ receptor as viewed from above, i.e., from the extracellular side. There are two binding sites for the physiological ligand GABA that are located between an $\alpha$ and a $\beta$ subunit, and there is one binding site for benzodiazepines at the interface of the $\gamma$ and an $\alpha$ subunit. Right panel: Cross section at the level of the plasma membrane. The numbers $1-4$ in each of the five receptor subunits depict the transmembrane regions of $\alpha$ subunit. There is strong evidence that the transmembrane region 2 of the $\beta$ subunit is a component of the binding site for intravenous anesthetics such as etomidate and propofol. As numerous classes of general anesthetics interact with etomidate binding at the $\mathrm{GABA}_{\mathrm{A}}$ receptor, ${ }^{96}$ this binding site appears to be in close proximity to or overlapping with a binding site of volatile anesthetics. Figure 1 reproduced with permission from ${ }^{97}$ 
$\mathrm{GABA}_{\mathrm{A}}$ receptors in the hippocampus. ${ }^{27,28}$ Thus, it is not surprising that the etomidate enhancement of tonic inhibitory currents in CA1 pyramidal neurons was blocked by the application of L-655,708, a $\alpha 5 \mathrm{GABA}_{\mathrm{A}}$ preferring inverse agonist. ${ }^{23}$ Moreover, long-term potentiation (LTP) of field excitatory postsynaptic potentials (EPSPs), a measure widely accepted as a molecular substrate for memory, was reduced by etomidate in hippocampal slices from wild type mice but not from $\alpha 5$ knockout mice. ${ }^{11}$

Behavioural findings from Pavlovian fear conditioning and hippocampus-dependent memory tasks, such as the Morris water maze, corroborate the data from electrophysiological studies. In the Morris water maze, mice treated with etomidate before the training session showed similar acquisition as vehicle-treated mice. However, recall of the platform location $24 \mathrm{hr}$ later was severely impaired in the etomidate-treated animals. Moreover, this reduction in performance following etomidate treatment was not observed in $\alpha 5$ knockout mice. ${ }^{11,23}$ Similar findings were reported from Pavlovian fear conditioning studies, where etomidate significantly reduced contextual freezing $24 \mathrm{hr}$ after the acquisition session in wild type, but not in $\alpha 5$ knockout mice. The involvement of $\alpha 5$-containing $\mathrm{GABA}_{\mathrm{A}}$ receptors in the effects of etomidate seems to be limited to the amnestic effects. The $\alpha 5$ knockout mice did not show altered sensitivity to the sedative and hypnotic effects of etomidate, as quantified by rotarod, the LORR, and spontaneous motor activity levels. ${ }^{11}$

Similarly, genetic inactivation of the $\alpha 4$ subunit affected LORR minimally and had no effect on immobility in response to isoflurane administration. However, in a conditioned fear experiment, the amnestic action of isoflurane was reduced in $\alpha 4$ knockout animals, implicating $\alpha 4$ containing $\mathrm{GABA}_{\mathrm{A}}$ receptors in the amnestic actions of this volatile anesthetic drug. ${ }^{29}$

\section{$\mathrm{GABA}_{\mathrm{A}}$ receptor knock-in mice}

Specific amino acid residues in the transmembrane domains 2 and 3 of $\alpha$ and $\beta$ subunits are critical for allosteric modulation of $\mathrm{GABA}_{\mathrm{A}}$ receptors by volatile anesthetics. ${ }^{30}$ Point mutations have been identified in recombinant systems, which significantly reduce or abolish the action of selected volatile anesthetics while leaving the physiological functions of the receptors largely intact. ${ }^{30}$ For example, a double point mutation in the $\alpha 1$ subunit, $\alpha 1(\mathrm{~S} 270 \mathrm{H} / \mathrm{L} 277 \mathrm{~A})$ renders $\alpha 1$-containing $\mathrm{GABA}_{\mathrm{A}}$ receptors insensitive to isoflurane, but not to halothane. ${ }^{31}$ Behaviourally, mice carrying this mutation are more resistant to LORR in response to isoflurane and enflurane, but not to halothane. On the other hand, the immobilizing action of isoflurane, desflurane, and halothane in the
TCWR test and the amnestic action of isoflurane in a fear conditioning paradigm were not different between the mutant and the wild type mice, indicating that $\alpha 1$-containing $\mathrm{GABA}_{\mathrm{A}}$ receptors play a limited role in the hypnotic action (LORR), but apparently play no role in the immobilizing action (TCWR) and in the amnestic action (fear conditioning). ${ }^{32}$ Moreover, etomidate, but not pentobarbital, decreased a smaller amount of time on the rotating rod in the mutant mice than in the wild type mice, indicating an involvement of $\alpha 1$-containing $\mathrm{GABA}_{\mathrm{A}}$ receptor in ataxic effects of etomidate. ${ }^{33}$

Naturally occurring $\mathrm{GABA}_{\mathrm{A}}$ receptors differ in their sensitivity to etomidate. Studies on the Rdl-receptor from Drosophila melanogaster, a close relative of the mammalian $\mathrm{GABA}_{\mathrm{A}}$ receptor, revealed that this receptor is insensitive to etomidate. ${ }^{34,35}$ In the second transmembrane region, this etomidate-insensitive $R d l$-receptor carries the amino acid, methionine, at a position corresponding to the asparagine (N265) of the $\beta 2$ and $\beta 3$ subunit in etomidatesensitive $\mathrm{GABA}_{\mathrm{A}}$ receptors. Similarly, $\beta 1$-containing $\mathrm{GABA}_{\mathrm{A}}$ receptors, which are an order of magnitude less sensitive to etomidate, ${ }^{36,37}$ carry a serine residue at the corresponding position. It was shown that mutation of this asparagine $(\mathrm{N})$ in $\beta 2$ or $\beta 3$ to serine (S) or methionine $(\mathrm{M})$ renders $\mathrm{GABA}_{\mathrm{A}}$ receptors etomidate-insensitive. While the $\beta 2(\mathrm{~N} 265 \mathrm{~S})$ mutation rendered receptors insensitive to etomidate but sensitive to propofol, the $\beta 3(\mathrm{~N} 265 \mathrm{M})$ mutation rendered receptors insensitive to both etomidate and propofol. ${ }^{38-40}$ Mice carrying these two mutations have revealed interesting insights into the contribution of $\beta 2$ - and $\beta 3$-containing $\mathrm{GABA}_{\mathrm{A}}$ receptors to anesthetic responses.

In $\beta 2(\mathrm{~N} 265 \mathrm{~S})$ mice, the sedative action of subanesthetic doses of etomidate, i.e., the inhibition of locomotor activity, was absent, while the LORR and the pedal withdrawal reflex were still present, although reduced. ${ }^{41}$ Moreover, the hypothermic response to etomidate was inhibited in these mice. ${ }^{42}$ In contrast, in $\beta 3(\mathrm{~N} 265 \mathrm{M})$, the LORR duration in response to etomidate and propofol was reduced, while the hindlimb withdrawal reflex was not lost, indicating that $\beta 3$-containing $\mathrm{GABA}_{\mathrm{A}}$ receptors are indispensible for the immobilizing actions of etomidate and propofol (Fig. 2). The hypnotic actions of these agents, on the other hand, are mediated by both $\beta 2$ - and $\beta 3$-containing $\mathrm{GABA}_{\mathrm{A}}$ receptors. ${ }^{43}$ This phenotype is robust, since it was observed on three different genetic backgrounds (129X1/SvJ, C57BL/ $6 \mathrm{~J}$, mixed background). ${ }^{13}$ The sedative, i.e., locomotor activity reducing, effect of a subanesthetic dose of etomidate was indistinguishable in wild type and $\beta 3(\mathrm{~N} 265 \mathrm{M})$ mice. ${ }^{44}$ The hypothermic action of etomidate was moderately reduced in $\beta 3(\mathrm{~N} 265 \mathrm{M})$ mice, ${ }^{44}$ indicating that $\beta 3$-containing $\mathrm{GABA}_{\mathrm{A}}$ receptors also play a role although this action is largely mediated by $\beta 2$-containing $\mathrm{GABA}_{\mathrm{A}}$ 
A wild type

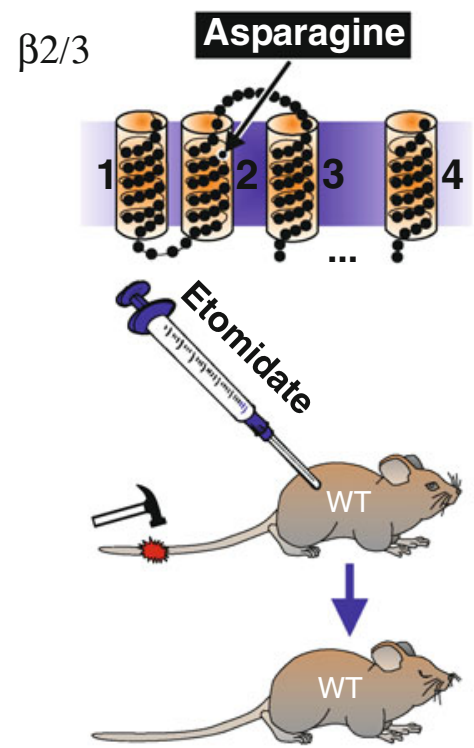

B $\quad \beta 2(\mathrm{~N} 265 \mathrm{~S})$ mutant

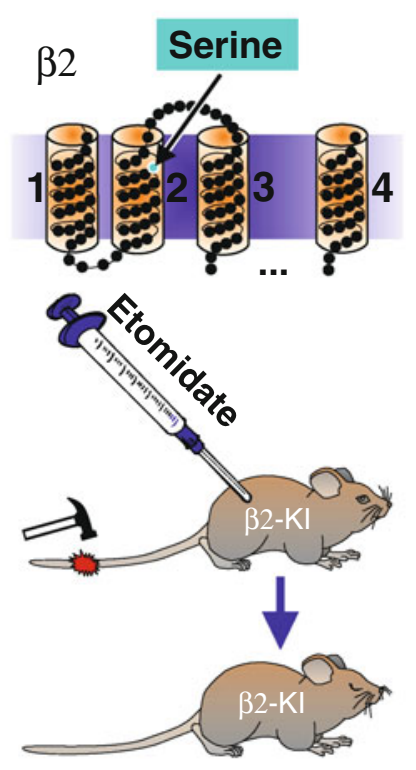

C $\beta 3(\mathrm{~N} 265 \mathrm{M})$ mutant

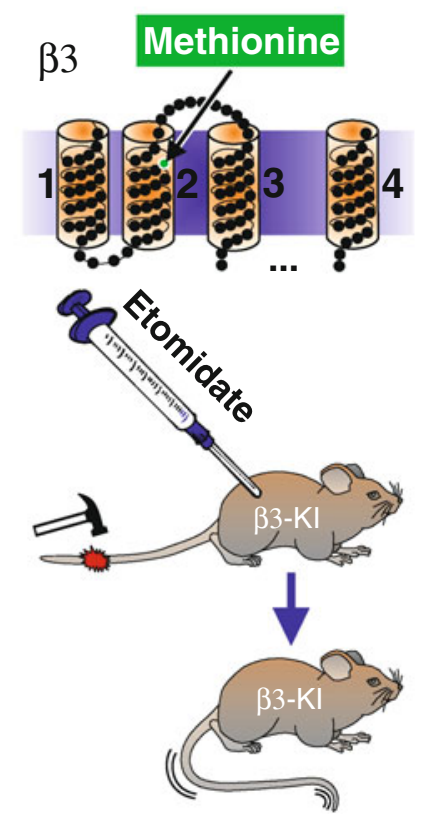

Fig. 2 Immobilizing action of etomidate in wild type, $\beta 2(\mathrm{~N} 265 \mathrm{~S})$ and $\beta 3(\mathrm{~N} 265 \mathrm{M})$ knock-in mice. Panel $A$ depicts wild type mice, panel $B$ depicts $\beta 2(\mathrm{~N} 265 \mathrm{~S})$ mice, $^{41}$ and panel $C$ depicts $\beta 3(\mathrm{~N} 265 \mathrm{M})$ mice. $^{43}$ At the top of all panels, the $\beta 2$ or $\beta 3$ subunit of the gammaaminobutyric acid $(\mathrm{GABA})_{\mathrm{A}}$ receptor with its four transmembrane domains is shown. A. At position 265 , the naturally occurring amino acid in both the $\beta 2$ and the $\beta 3$ subunit is asparagine (single letter code $\mathrm{N}$ ). When a wild type mouse is injected with etomidate, pain reflexes (for illustrative purposes a hammer blow on the tail is shown, while actually paw withdrawal reflexes were assayed) are suppressed, i.e., the animal is immobilized by the general anesthetic. B. By introducing the $\mathrm{N} 265 \mathrm{~S}$ mutation into the $\beta 2$ subunit of the $\mathrm{GABA}_{\mathrm{A}}$ receptor, this receptor subtype is essentially no longer modulated by etomidate. However, after injection of etomidate, the mouse still does not show a motor reaction in response to a painful stimulus, indicating that $\beta 2$-containing $\mathrm{GABA}_{\mathrm{A}}$ receptors are dispensable for the immobilizing actions of etomidate. ${ }^{41} \mathrm{C}$. The $\mathrm{N} 265 \mathrm{M}$ point mutation in the $\beta 3$ subunit of the $\mathrm{GABA}_{\mathrm{A}}$ receptor renders $\beta 3$-containing $\mathrm{GABA}_{\mathrm{A}}$ receptors insensitive to modulation by etomidate. After injection of etomidate, the animals still show pain reflexes, demonstrating that $\mathrm{GABA}_{\mathrm{A}}$ receptors harbouring $\beta 3$ subunits are indispensable for the immobilizing properties of etomidate. ${ }^{43} \mathrm{KI}=$ knock-in. Figure 2 reproduced with permission from ${ }^{97}$ receptors. Etomidate and propofol lead to respiratory depression in wild type mice. In $\beta 3(\mathrm{~N} 265 \mathrm{M})$ mice, $\mathrm{PaCO} 2$ was significantly lower, $\mathrm{PaO} 2$ was significantly higher, and the $\mathrm{pH}$ value was significantly higher than in wild type mice, indicating that the respiratory depression is mediated by $\beta 3$-containing $\mathrm{GABA}_{\mathrm{A}}$ receptors. ${ }^{44}$ In contrast, heart rate depression as well as ECG changes were still present in $\beta 3(\mathrm{~N} 265 \mathrm{M})$ mice, indicating that they may be mediated by $\beta 2$-containing $\mathrm{GABA}_{\mathrm{A}}$ receptors. ${ }^{44}$ The anterograde amnestic action of propofol, as studied in the passive avoidance paradigm, was indistinguishable in $\beta 3(\mathrm{~N} 265 \mathrm{M})$ mice and wild type mice, indicating that it is not mediated by $\beta 3$-containing $\mathrm{GABA}_{\mathrm{A}}$ receptors. ${ }^{13}$ While the receptor subtype mediating this action is unknown, it is worth noting that the anterograde amnestic action of diazepam has been shown to be mediated, at least in part, by $\alpha 1$-containing $\mathrm{GABA}_{\mathrm{A}}$ receptors, ${ }^{2}$ presumably of an $\alpha 1 \beta 2 \gamma 2$ composition. ${ }^{45}$ The roles of the $\beta 2$ and $\beta 3$ subunits for the major anesthetic actions of etomidate and propofol are summarized in Fig. 3. Results largely similar to those for etomidate and propofol were obtained for the barbiturate pentobarbital, in the $\beta 3(\mathrm{~N} 265 \mathrm{M})$ mice, with the major exception that the respiratory depressant action of pentobarbital is present in $\beta 3(\mathrm{~N} 265 \mathrm{M})$ mice, indicating that other as yet unidentified receptor targets of pentobarbital can mediate this action. ${ }^{46}$

Finally, the $\beta 3(\mathrm{~N} 265 \mathrm{M})$ mutation also inhibits the actions of the volatile anesthetics ${ }^{40}$ and has some relatively minor influence on the immobilizing action of halothane, isoflurane, and enflurane, while the mutation has essentially no effect on the hypnotic actions of these agents. $^{12,43,47}$

\section{Glutamate receptors}

Glutamate receptors are responsible for a large portion of excitatory neurotransmission in the mammalian nervous system. Ionotropic glutamate receptors (iGluRs) consist of four subunits that form an ion channel. Three categories of 


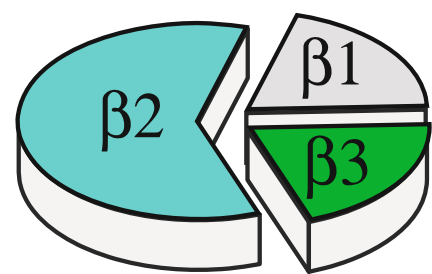

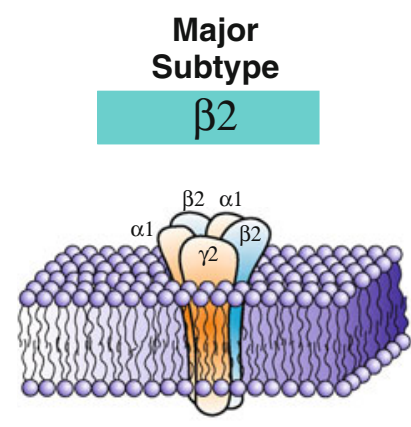

- Hypnosis, in part

- Sedation

- Hypothermia

Fig. 3 Contribution of $\beta 2$ - and $\beta 3$-containing gamma-aminobutyric acid $(\mathrm{GABA})_{\mathrm{A}}$ receptors to anesthetic endpoints and adverse effects of etomidate and propofol. Figure 3 reproduced with permission from $^{97}$

iGluRs have been defined based on their activation characteristics by different agonists: (1) NMDA receptors, (2) AMPA receptors, and (3) kainate receptors. Metabotropic glutamate receptors (mGluRs) carry transmembrane segments similar to other G-protein coupled receptors and an extracellular ligand binding domain similar to that of iGluRs. ${ }^{48}$

Glutamate-mediated neurotransmission is attenuated by several volatile and gaseous anesthetics. ${ }^{49,50}$ This raises the possibility that anesthetic endpoints of at least some compounds are mediated by glutamate receptors. A small body of work has focused on the effects of anesthetics on NMDA and AMPA receptors.

NMDA receptors are tetrameric transmembrane channels composed of an GluN1 subunit (previously also called NR1 or GluR $\xi 1$ ) combined with GluN2 (previously also called NR2 or GluRe) and/or GluR3 subunits. ${ }^{51}$ Eight functional splice variants have been noted for the GluN1 subunit, ${ }^{52}$ while four types of GluN2 (GluN2A-D) and two types of NR3 (NR3A-B) subunits are encoded by separate genes. ${ }^{53}$ Some anesthetics, such as nitrous oxide and ketamine, have minimal effects on $\mathrm{GABA}_{\mathrm{A}}$ receptors, but they potently inhibit NMDA receptors. ${ }^{50,54}$ Thus, it is possible that the behavioural effects of these anesthetic drugs are mediated, at least partially, by their NMDA-inhibiting actions. A number of studies by Sato et al. ${ }^{55,56}$ demonstrated that the hypnotic effects of ketamine and nitrous oxide were attenuated in NMDA receptor NR2A subunit knockout mice, specifying the NR2A subunit as one of the targets of these drugs. However, the deletion of the NR2A subunit also dampened the LORR induced by mainly GABAergic agents, such as pentobarbital, diazepam, and midazolam, suggesting that the behavioural phenotype might be due, at least in part, to compensatory mechanisms secondary to the NR2A knockout, which also affect other neurotransmitter systems.

AMPA receptors are tetramers made up of combinations of four subunits: GluA1, GluA2, GluA3, and GluA4 (previously also called GluRA-D, GluR1-4). ${ }^{57}$ AMPA receptor properties are predominantly determined by the GluA2 subunit, which conveys calcium permeability of the receptors. GluA2 subunit-containing AMPA receptors are inhibited by barbiturates, whereas the deletion of the GluA2 subunit renders AMPA receptors predominantly insensitive to barbiturate effects. ${ }^{58}$ Interestingly, GluA2 knockout mice show increased sensitivity to barbiturateinduced LORR. Moreover, the same kind of hypersensitivity was observed to the effects of volatile anesthetics isoflurane, halothane, sevoflurane, and desflurane, which do not affect AMPA-receptor activity at clinically relevant concentrations, suggesting compensatory mechanisms in GluA2 knockout mice. ${ }^{59}$ These findings suggest that caution is required when attributing the changes in behavioural endpoints to receptor-drug interactions. In this case, the increased LORR-sensitivity is likely a result of downstream alterations in other systems caused by the genetic modification rather than the genetically-modified receptor system itself.

\section{Other ion channels with relevance for anesthesia}

Two-pore domain background potassium channels modulate neuronal excitability. There are five subunits (TREK-1, TREK-2, TASK-1, TASK-3, and TRESK) known that can homo- and heterodimerize, and channels are found both pre- and postsynaptically. All five subunits can be modulated by halothane, but they are insensitive to clinically relevant concentrations of intravenous anesthetics. In TREK-1 knockout mice, the concentrations of the volatile anesthetics, chloroform, halothane, sevoflurane, and desflurane, required for LORR were increased significantly, although the effect size was small as were the concentrations required for immobilization in the TCWR assay, indicating that TREK-1 plays a limited role in mediating the hypnotic and immobilizing actions of these volatile anesthetics. ${ }^{60}$ The concentration of halothane required for LORR was similar in TASK-1 knockout mice and wild 
type mice; however, in TASK-1 knockout mice, a higher concentration of isoflurane was required for LORR. Conversely, the concentration of halothane, but not of isoflurane, required for suppression of tail clamp withdrawal was increased. ${ }^{61}$ Similarly, TASK-3 knockout mice require higher concentrations of halothane, but not of isoflurane, for suppression of the TCWR. ${ }^{62}$ These results indicate a relatively limited but nevertheless significant role of TASK-1 and TASK-3 channels in the hypnotic and immobilizing actions of volatile anesthetics, in line with the idea that volatile anesthetics likely have multiple molecular targets.

Another relevant example of a mouse model providing insights into actions of general anesthetics is provided by TRPA1 knockout mice. In these mice, the volatile anesthetic, desflurane, and the intravenous anesthetic, propofol, fail to excite dorsal root ganglion neurons and thus to activate nociceptive neurons, indicating that TRPA1 channels mediate pronociceptive actions of general anesthetics. $^{63}$

\section{From behavioural endpoints of anesthesia to isolated neuronal networks}

The two in vivo studies from Reynolds et $a .^{41}$ and Jurd et $a l^{43}$ indicated that different endpoints of general anesthetics are mediated by distinct populations of $\mathrm{GABA}_{\mathrm{A}}$ receptor subtypes. As these distinct receptor populations are differentially distributed in the central nervous system, this finding also nicely corroborates the idea that individual endpoints of general anesthetics are mediated by neuronal populations in different brain regions. The cerebral cortex has been shown to mediate sedation induced by volatile anesthetics ${ }^{64}$ and benzodiazepines, ${ }^{6}$ which is in line with the observation that $\beta 2$-containing $\mathrm{GABA}_{\mathrm{A}}$ receptors (contained in the most abundant receptor subtype $\alpha 1 \beta 2 \gamma 2$ ) are highly expressed in this brain region. Cortical and subcortical structures mediate hypnosis, and express both $\beta 2$ and $\beta 3 .^{65}$ The immobilizing action of general anesthetics, including etomidate and propofol, has been shown to be largely dependent on the spinal cord, ${ }^{66-69}$ which displays high expression of $\beta 3 .^{70}$ The observation that distinct subpopulations of $\mathrm{GABA}_{\mathrm{A}}$ receptor subtypes in different parts of the central nervous system mediate different endpoints of general anesthesia, such as hypnosis and immobility, offers the possibility to perform studies using specific isolated networks, e.g., the cortex or the spinal cord. Such studies in isolated networks can bring deeper insights into the mechanisms of anesthesia and are useful in vitro systems for the development and testing of new drugs (Fig. 4).

\section{Testing specific neuronal networks ex vivo: cortex}

As outlined above, selectivity for general anesthetic actions is observed at the molecular and the behavioural level. Thus, it seems reasonable to assume that this might as well be mirrored on the level of neuronal networks. Organotypic slice cultures from the neocortex are one example of an isolated neuronal network. They were introduced by Gähwiler in $1981^{71}$ and have been proven to show in-vivolike morphology, physiology and, most importantly for neuropharmacological studies, $\mathrm{GABA}_{\mathrm{A}}$ receptor subtype distribution. $^{72-75}$ Moreover, as the diffusion of anesthetics into the tissue is comparatively fast, ${ }^{76,77}$ organotypic slice cultures are an ideal tool for investigating anesthetic actions.

Rhythmic electrical activity, i.e., oscillations, is a physiological feature of both in vivo and in vitro networks. Oscillations in various frequency bands can be recorded from neocortical slice cultures by means of extracellular electrodes (for review see reference 78). Oscillations in the theta range $(4-12 \mathrm{~Hz}$ ) are associated with delayed memory tasks and sensorimotor integration. ${ }^{79}$ The generation of theta oscillations depends on rhythmic firing of specific GABAergic interneurons, synchronizing the network. ${ }^{80}$

Etomidate is a positive modulator of GABAergic inhibition, acting predominantly via $\beta 2$ - and $\beta 3$-containing $\mathrm{GABA}_{\mathrm{A}}$ receptors. It is possible that these two subpopulations of $\mathrm{GABA}_{\mathrm{A}}$ receptors (those containing $\beta 2$ - and those containing $\beta 3$-subunits) belong to different inhibitory networks. By using $\beta 3(\mathrm{~N} 265 \mathrm{M})$ point mutant mice, where etomidate actions are largely restricted to $\beta 2$-containing $\mathrm{GABA}_{\mathrm{A}}$ receptors, these networks and their impact on cortical theta oscillations can be experimentally separated. Indeed, cortical theta oscillations were found to be depressed in organotypic slice cultures from the neocortex of $\beta 3(\mathrm{~N} 265 \mathrm{M})$ mice, while no depression was observed in wild type slices. ${ }^{81}$ By this experimental separation of the two networks, it was demonstrated that etomidate induces opposing actions on cortical oscillations via different $\mathrm{GABA}_{\mathrm{A}}$ receptor populations.

Isolated neuronal networks are also a valuable tool for the investigation of the mechanism of action of general anesthetics. As mentioned above, the two intravenous anesthetics, etomidate and propofol, share their main molecular targets, namely $\mathrm{GABA}_{\mathrm{A}}$ receptors harbouring $\beta 2$ - and $\beta 3$-subunits. While etomidate favours $\beta 3$ and $\beta 2$ over $\beta 1$, propofol is rather unselective in this regard. ${ }^{36,37}$ From daily clinical practice, we know that etomidate and propofol have distinct clinical profiles. For instance, etomidate, but not propofol, produces myoclonic movements. ${ }^{82}$ Specifically, when used as an anesthetic for electroconvulsive therapy, etomidate increases seizures, while propofol shortens seizures. ${ }^{83,84}$ Finally, if sensory-evoked potentials 


\begin{tabular}{|c|c|c|}
\hline Syste & Major Findings & Ref. \\
\hline GAB & $\begin{array}{l}\text { - Rdl-receptor from Drosophila, although similar to the } \\
{\text { mammalian } \mathrm{GABA}_{A} \text { receptor, is insensitive to etomidate }} \\
\text { - Etomidate favors } \beta 3 \text { and } \beta 2 \text { over } \beta 1 \text {-containing } \\
\mathrm{GABA}_{A} \text { receptors, while propofol does not } \\
\text { - The interactions of etomidate and propofol with the } \\
\mathrm{GABA}_{A} \text { receptor are influenced by one single amino acid }\end{array}$ & $\begin{array}{l}{[34]} \\
{[36,37]} \\
{[38,40]}\end{array}$ \\
\hline & $\begin{array}{l}\text { - } \beta 3 \text {-containing } \mathrm{GABA}_{A} \text { receptors mediate the immobilizing } \\
\text { and hypnotic properties of etomidate and propofol } \\
\text { - } \beta 2 \text {-containing } \mathrm{GABA}_{\mathrm{A}} \text { receptors mediate the sedative } \\
\text { properties of etomidate } \\
\text { - Respiratory depression by etomidate and propofol are } \\
\text { mediated by } \beta 3 \text {-containing } \mathrm{GABA}_{A} \text { receptors } \\
\text { - } \beta 3 \text {-containing } \mathrm{GABA} \mathrm{A}_{\mathrm{A}} \text { receptors mediate the immobilizing, } \\
\text { part of the hypnotic, but not the respiratory depression } \\
\text { by pentobarbital } \\
\text { - Etomidate-induced hypothermia is mediated mainly } \\
\text { by } \beta 2 \text {-containing } \mathrm{GABA}_{A} \text { receptors } \\
\text { - Etomidate induced amnesia is mediated by } \\
\alpha 5 \text {-containing } \mathrm{GABA}_{A} \text { receptors }\end{array}$ & $\begin{array}{l}{[43]} \\
{[41]} \\
{[44]} \\
{[46]} \\
{[42,44]} \\
{[11]}\end{array}$ \\
\hline & $\begin{array}{l}\text { - Etomidate induces opposing effects on cortical } \\
\text { theta oscillations via different } \mathrm{GABA}_{A} \text { receptor subtypes } \\
\text { - Etomidate and propofol show distinct actions } \\
\text { at } \beta 3 \text {-containing } \mathrm{GABA}_{A} \text { receptors } \\
\text { - The tuberomammillary nucleus and the perifornical area, } \\
\text { both being parts of natural sleep pathways, } \\
\text { are important targets of propofol } \\
\text { - } \beta 3 \text {-containing GABA } \mathrm{A}_{\mathrm{A}} \text { receptors are largely contributing } \\
\text { to depressant actions of etomidate in neuronal networks } \\
\text { of the ventral horn of the spinal cord }\end{array}$ & $\begin{array}{l}{[81]} \\
{[87]} \\
{[91]}\end{array}$ \\
\hline
\end{tabular}

Fig. 4 Important findings from molecular genetic studies with intravenous anesthetics

are used for monitoring purposes, etomidate enhances signal amplitude, but propofol does not. ${ }^{85,86}$ But how can we explain these evidently different clinical profiles of etomidate and propofol considering their largely overlapping molecular targets, in particular $\beta 2$ - and $\beta 3$-containing $\mathrm{GABA}_{\mathrm{A}}$ receptors? One possible explanation can be found 
in their effects on the firing patterns of cortical networks. A typical firing pattern of isolated cortical networks is characterized by bursts of action potential firing separated by neuronal silence. Etomidate and propofol were shown to have differential effects on this typical firing pattern. Etomidate shortened the bursts and reduced the number of action potentials per bursts. These effects were absent in $\beta 3$ $(\mathrm{N} 265 \mathrm{M})$ mutant slices, indicating that these actions are mediated by $\beta 3$-containing $\mathrm{GABA}_{\mathrm{A}}$ receptors. In contrast, propofol increased burst length. ${ }^{87}$

The differential effects of etomidate and propofol are also detectable at the synaptic level. The actions of GABAergic synapses can be recorded as inhibitory postsynaptic currents. An inhibitory postsynaptic current is characterized by an initial very steep rising phase, a first phase of rapid current decay and a second phase of slow current decay. In cortical slice cultures, etomidate exclusively affected the slow phase, while propofol had effects on both phases of the current decay. ${ }^{87}$ These results indicate the following: (1) the differential clinical effects of etomidate and propofol are mirrored on the level of the cortical network and also on the level of the GABAergic synapse; and (2) as the effects of both drugs were qualitatively different in slices from $\beta 3(\mathrm{~N} 265 \mathrm{M})$ mutant mice compared with wild type mice, they can be attributed to different subpopulations of $\mathrm{GABA}_{\mathrm{A}}$ receptors. These results support the view that differences in the molecular interactions of anesthetics with their targets lead to distinguishable differences in network firing effects, which finally translate into distinct clinical profiles (Fig. 5).

Besides cortical networks, subcortical structures are also important targets for general anesthetics. ${ }^{88,89}$ In particular, endogenous sleep pathways appear to play a prominent role. $^{90}$ In support of this hypothesis, studies using $\beta 3(\mathrm{~N} 265 \mathrm{M})$ knock-in mutant mice showed that the effect of propofol on the decay time of GABAergic currents was dependent on $\beta 3$-containing $\mathrm{GABA}_{\mathrm{A}}$ receptors in the tuberomammillary nucleus and the perifornical area, but not in the locus coeruleus. Thus, the $\beta 3$-containing $\mathrm{GABA}_{\mathrm{A}}$ receptors in the tuberomammillary nucleus and the perifornical area, but not in the locus coeruleus, may be direct targets for the hypnotic action of propofol. ${ }^{91}$

\section{Testing specific neuronal networks ex vivo: spinal cord}

The spinal cord is probably the most important part of the central nervous system mediating the general anesthetic endpoint immobility. ${ }^{66-69}$ As mentioned before, in $\beta 3(\mathrm{~N} 265 \mathrm{M})$ mutant mice, the immobilizing actions of etomidate and propofol were abolished. ${ }^{43}$ Thus, it was not surprising that the network-depressing effects of etomidate were also reduced significantly in cultured spinal cord slices from these knock-in mice. However, using cultured spinal cord slices from $\beta 3(\mathrm{~N} 265 \mathrm{M})$ mutant mice, the authors demonstrated that (1) the depression of ventral horn neurons by etomidate is limited to approximately $60 \%$; and (2) this limitation is most likely based on the fact that etomidate also depresses presynaptic GABA release. ${ }^{92}$ As etomidate action (positive modulation of GABAergic inhibition) most likely depends on the presence of the physiological neurotransmitter GABA, this means that etomidate literally "bites the hand that feeds it" by depressing presynaptic GABA release, resulting in only partial depression of ventral horn neurons. As this presynaptic effect of etomidate was absent in $\beta 3(\mathrm{~N} 265 \mathrm{M})$ mutant spinal slices, it can be concluded that this selfrestrictive and, hence, undesired effect of etomidate is mediated by $\beta 3$-containing $\mathrm{GABA}_{\mathrm{A}}$ receptors that are presynaptically located. ${ }^{92}$ This example illustrates that electrophysiological studies of isolated neuronal networks using tissues derived from knock-in mice are an elegant approach for investigating mechanisms of action of general anesthetics and also for testing the immobilizing properties of novel compounds. ${ }^{93}$

\section{Multiple targets of volatile anesthetics}

As mentioned previously, the volatile anesthetics interact with multiple molecular targets, including $\mathrm{GABA}_{\mathrm{A}}$ receptors. $^{9}$ For electrophysiological studies on $\mathrm{GABA}_{\mathrm{A}}$ receptors, perhaps the best model substance is enflurane, because it displays most prominently the typical effects of volatile anesthetics on inhibitory postsynaptic GABAergic currents, i.e., prolongation of decay time and reduction of the current amplitude. Distinct mechanisms have been suggested to underlie these two actions. ${ }^{94}$ Both actions of enflurane were abolished in cortical slice cultures from $\mathrm{GABA}_{\mathrm{A}}$ receptor $\beta 3(\mathrm{~N} 265 \mathrm{M})$ mutant mice, demonstrating that $\beta 3$-containing $\mathrm{GABA}_{\mathrm{A}}$ receptors are involved in both mechanisms. ${ }^{95}$

\section{Clinical implications}

A crucial factor in choosing a drug for inducing anesthesia in a specific clinical setting is the pattern of potential adverse side effects. In fact, all anesthetic agents in current use display a long list of unwanted actions, including cardiovascular instability, hypothermia and postoperative shivering, respiratory depression, postoperative vomiting, and nausea. The molecular and cellular mechanisms contributing to these side effects remain to be elucidated. Interestingly, studies on genetically modified mice provided first evidence that certain $\mathrm{GABA}_{\mathrm{A}}$ receptor subtypes 
Fig. 5 Comparison of the properties of etomidate and propofol at different levels of observation. A. The intravenous anesthetics, etomidate and propofol, have largely overlapping gammaaminobutyric acid $(\mathrm{GABA})_{\mathrm{A}}$ receptor targets (etomidate: $\beta 2$, $\beta 3$; propofol: $\beta 1-\beta 3){ }^{36,37}$ The differently sized arrows symbolize that propofol apparently has no preference, while etomidate has some preference for $\mathrm{GABA}_{\mathrm{A}}$ receptor subpopulations ("S1", "S2").

B. Different subtypes of $\mathrm{GABA}_{\mathrm{A}}$ receptors display different regional and cellular localizations, physiological, and pharmacological

properties, ${ }^{98-100}$ e.g., while one subpopulation might be predominant in the upper layers of the cerebral cortex, it might be only a minor subtype in deeper layers and vice versa. This results in a differential representation of receptor subpopulations in neuronal networks. C, D. The

combination of the differences described in $\mathrm{A}$ and $\mathrm{B}$ (i.e., preference of $\mathrm{GABA}_{\mathrm{A}}$ receptor subpopulation "S1" by etomidate and equal action of propofol at "S1" and "S2") together with the differential localization of the two receptor subpopulations within a neuronal network leads to differential electrophysiological network effects ${ }^{87}$ and clinical effects of etomidate and propofol
A

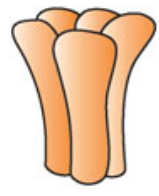

Targetreceptors
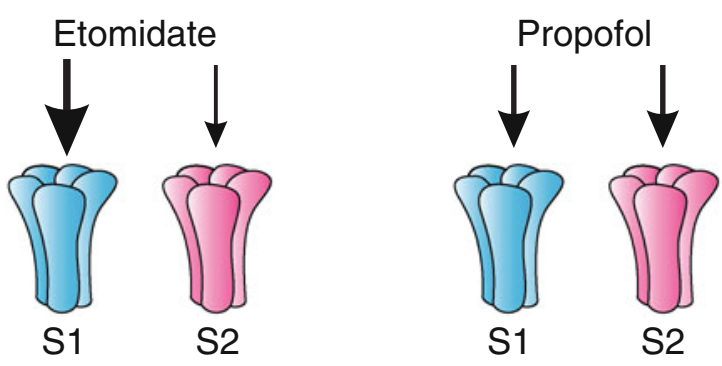

B

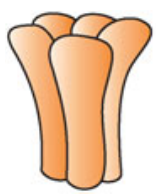

Receptorlocalization

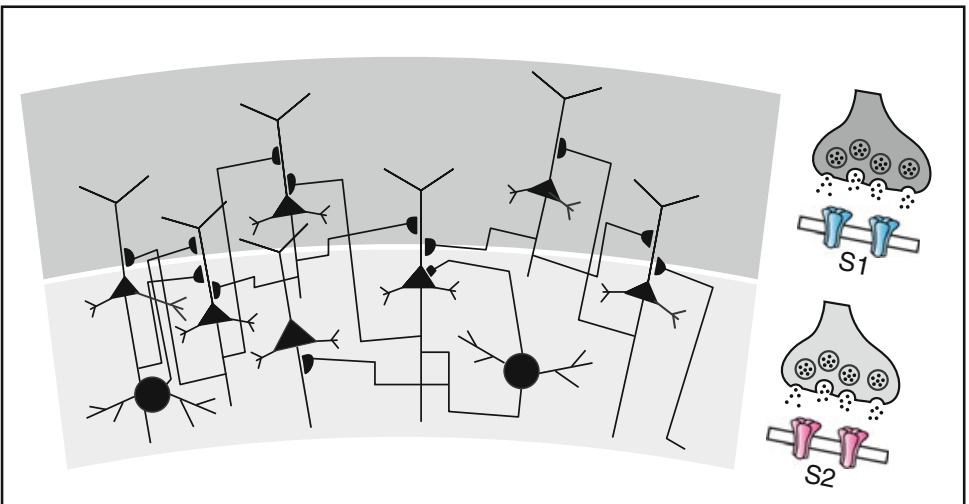

C

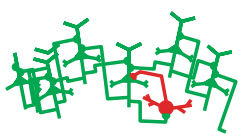

Neuronal Activity

Etomidate

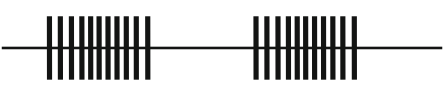

Propofol

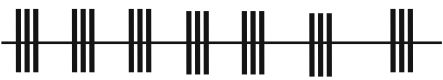

D

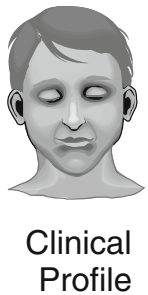

\begin{tabular}{|l|c|c|}
\hline Parameter & Etomidate & Propofol \\
\hline $\begin{array}{l}\text { ECT-induced } \\
\text { seizures }\end{array}$ & $\begin{array}{l}\text { Duration } \\
\text { increased }\end{array}$ & $\begin{array}{l}\text { Duration } \\
\text { reduced }\end{array}$ \\
\hline $\begin{array}{l}\text { Evoked } \\
\text { Potentials }\end{array}$ & $\begin{array}{l}\text { Amplitude } \\
\text { enhanced }\end{array}$ & no effect \\
\hline $\begin{array}{l}\text { Myoclonic } \\
\text { Movements }\end{array}$ & pronounced & none \\
\hline
\end{tabular}

mediate unconsciousness and immobility, whereas others are involved in causing cardiovascular depression and hypothermia. ${ }^{43,44}$ These findings suggest that the desired and undesired clinical actions of anesthetics are mediated, at least in part, by different molecular targets. Thus, improving the selectivity of anesthetic agents may open new avenues for the development of new compounds with an improved side effect profile. Indeed, there is a need for improved anesthetic compounds, in particular for high-risk populations as well as in very young and very old patients.

\section{Conclusions}

Research on genetically modified mice, e.g., knockout and knock-in mutants, has led to significant progress in the identification and functional characterization of the 
anesthetic targets in the central nervous system. These investigations define the scientific basis for the rational design of improved anesthetic compounds in the future. Furthermore, combined in vitro and in vivo studies provide important clues about the specific functions of neural networks and ion channels during wakefulness, sleep, and general anesthesia.

Acknowledgements The authors are supported by grant No. AN 321 / 2-1 from the German Research Foundation (DFG) and award number GM086448 from the National Institutes of Health. The content is solely the responsibility of the authors and does not necessarily represent the official views of the National Institute of General Medical Sciences or the National Institutes of Health.

Conflict of interest None declared

\section{References}

1. Krasowski MD, Harrison NL. General anaesthetic actions on ligand-gated ion channels. Cell Mol Life Sci 1999; 55: 1278-303.

2. Rudolph $U$, Crestani $F$, Benke $D$, et al. Benzodiazepine actions mediated by specific gamma-aminobutyric acid $_{\mathrm{A}}$ receptor subtypes. Nature 1999; 401: 796-800.

3. McKernan RM, Rosahl TW, Reynolds DS, et al. Sedative but not anxiolytic properties of benzodiazepines are mediated by the GABA(A) receptor alpha1 subtype. Nat Neurosci 2000; 3: 587-92.

4. Kralic JE, O'Buckley TK, Khisti RT, Hodge CW, Homanics GE, Morrow AL. GABA(A) receptor alpha-1 subunit deletion alters receptor subtype assembly, pharmacological and behavioral responses to benzodiazepines and zolpidem. Neuropharmacol 2002; 43: 685-94.

5. Sur C, Wafford KA, Reynolds DS, et al. Loss of the major GABA(A) receptor subtype in the brain is not lethal in mice. J Neurosci 2001; 21: 3409-18.

6. Zeller A, Crestani F, Camenisch I, et al. Cortical glutamatergic neurons mediate the motor sedative action of diazepam. Mol Pharmacol 2008; 73: 282-91.

7. Brickley SG, Revilla V, Cull-Candy SG, Wisden W, Farrant M. Adaptive regulation of neuronal excitability by a voltage-independent potassium conductance. Nature 2001; 409: 88-92.

8. Rudolph $U$, Moehler $H$. Analysis of $\mathrm{GABA}_{\mathrm{A}}$ receptor function and dissection of the pharmacology of benzodiazepines and general anesthetics through mouse genetics. Annu Rev Pharmacol Toxicol 2004; 44: 475-98.

9. Rudolph $U$, Antkowiak B. Molecular and neuronal substrates for general anaesthetics. Nat Rev Neurosci 2004; 5: 709-20.

10. Franks NP. General anaesthesia: from molecular targets to neuronal pathways of sleep and arousal. Nat Rev Neurosci 2008; 9: $370-86$.

11. Cheng VY, Martin LJ, Elliott EM, et al. Alpha5GABA $\mathrm{A}_{\mathrm{A}}$ receptors mediate the amnestic but not sedative-hypnotic effects of the general anesthetic etomidate. J Neurosci 2006; 26: 3713-20.

12. Liao M, Sonner JM, Jurd $R$, et al. Beta3-containing gammaaminobutyric $\operatorname{acid}_{\mathrm{A}}$ receptors are not major targets for the amnesic and immobilizing actions of isoflurane. Anesth Analg 2005; 101: 412-8.

13. Zeller A, Arras M, Jurd R, Rudolph U. Mapping the contribution of beta3-containing $\mathrm{GABA}_{\mathrm{A}}$ receptors to volatile and intravenous general anesthetic actions. BMC Pharmacol 2007; 7: 2.

14. Gallos $G$, Gleason NR, Zhang $Y$, et al. Activation of endogenous $\mathrm{GABA}_{\mathrm{A}}$ channels on airway smooth muscle potentiates isoproterenol-mediated relaxation. Am J Physiol Lung Cell Mol Physiol 2008; 295: L1040-7.

15. Xiang $Y Y$, Wang $S$, Liu $M$, et al. A GABAergic system in airway epithelium is essential for mucus overproduction in asthma. Nat Med 2007; 13: 862-7.

16. Homanics GE, Ferguson C, Quinlan JJ, et al. Gene knockout of the alpha6 subunit of the gamma-aminobutyric acid type A receptor: lack of effect on responses to ethanol, pentobarbital, and general anesthetics. Mol Pharmacol 1997; 51: 588-96.

17. Mihalek RM, Banerjee PK, Korpi ER, et al. Attenuated sensitivity to neuroactive steroids in gamma-aminobutyrate type A receptor delta subunit knockout mice. Proc Natl Acad Sci USA 1999; 96: 12905-10.

18. Quinlan JJ, Homanics GE, Firestone LL. Anesthesia sensitivity in mice that lack the beta3 subunit of the gamma-aminobutyric acid type A receptor. Anesthesiology 1998; 88: 775-80.

19. Sandin RH, Enlund G, Samuelsson P, Lennmarken C. Awareness during anaesthesia: a prospective case study. Lancet 2000; 355: 707-11.

20. Sebel PS, Bowdle TA, Ghoneim MM, et al. The incidence of awareness during anesthesia: a multicenter United States study. Anesth Analg 2004; 99: 833-9.

21. Orser BA, Mazer CD, Baker AJ. Awareness during anesthesia. CMAJ 2008; 178: 185-8.

22. Collinson N, Kuenzi FM, Jarolimek W, et al. Enhanced learning and memory and altered GABAergic synaptic transmission in mice lacking the alpha5 subunit of the $\mathrm{GABA}_{\mathrm{A}}$ receptor. J Neurosci 2002; 22: 5572-80.

23. Martin LJ, Oh GH, Orser BA. Etomidate targets alpha5 gammaaminobutyric acid subtype A receptors to regulate synaptic plasticity and memory blockade. Anesthesiology 2009; 111: 1025-35.

24. Caraiscos VB, Newell JG, You-Ten KE, et al. Selective enhancement of tonic GABAergic inhibition in murine hippocampal neurons by low concentrations of the volatile anesthetic isoflurane. J Neurosci 2004; 24: 8454-8.

25. Dai S, Perouansky M, Pearce RA. Amnestic concentrations of etomidate modulate GABAA, slow synaptic inhibition in hippocampus. Anesthesiology 2009; 111: 766-73.

26. Bieda MC, MacIver MB. Major role for tonic $\mathrm{GABA}_{\mathrm{A}}$ conductances in anesthetic suppression of intrinsic neuronal excitibility. J Neurophysiol 2004; 92: 1658-67.

27. Caraiscos VB, Elliott EM, You-Ten KE, et al. Tonic inhibition in mouse hippocampal CA1 pyramidal neurons is mediated by alpha5 subunit-containing gamma-aminobutyric acid type A receptors. Proc Natl Acad Sci USA 2004; 101: 3662-7.

28. Zarnowska ED, Keist $R$, Rudolph $U$, Pearce $R A$. GABAA receptor alpha5 subunits contribute to GABAA, slow synaptic inhibition in mouse hippocampus. J Neurophysiol 2009; 101: 1179-91.

29. Rau V, Iyer SV, Oh I, et al. Gamma-aminobutyric acid type A receptor alpha 4 subunit knockout mice are resistant to the amnestic effect of isoflurane. Anesth Analg 2009; 109: 1816-22.

30. Mihic SJ, Ye Q, Wick MJ, et al. Sites of alcohol and volatile anaesthetic action on $\operatorname{GABA}(\mathrm{A})$ and glycine receptors. Nature 1997; 389: 385-9.

31. Borghese CM, Werner DF, Topf $N$, et al. An isoflurane- and alcohol-insensitive mutant $\mathrm{GABA}(\mathrm{A})$ receptor alpha(1) subunit with near-normal apparent affinity for GABA: characterization in heterologous systems and production of knockin mice. J Pharmacol Exp Ther 2006; 319: 208-18.

32. Sonner JM, Werner DF, Elsen FP, et al. Effect of isoflurane and other potent inhaled anesthetics on minimum alveolar concentration, learning, and the righting reflex in mice engineered to express alphal gamma-aminobutyric acid type A receptors unresponsive to isoflurane. Anesthesiology 2007; 106: 107-13. 
33. Werner DF, Blednov YA, Ariwodola OJ, et al. Knockin mice with ethanol-insensitive alpha1-containing gamma-aminobutyric acid type A receptors display selective alterations in behavioral responses to ethanol. J Pharmacol Exp Ther 2006; 319: 219-27.

34. Belelli D, Callachan H, Hill-Venning C, Peters JA, Lambert JJ. Interaction of positive allosteric modulators with human and Drosophila recombinant GABA receptors expressed in Xenopus laevis oocytes. Br J Pharmacol 1996; 118: 563-76.

35. McGurk KA, Pistis M, Belelli D, Hope AG, Lambert JJ. The effect of a transmembrane amino acid on etomidate sensitivity of an invertebrate GABA receptor. Br J Pharmacol 1998; 124: 13-20.

36. Hill-Venning C, Belelli D, Peters JA, Lambert JJ. Subunitdependent interaction of the general anaesthetic etomidate with the gamma-aminobutyric acid type A receptor. $\mathrm{Br} \mathrm{J}$ Pharmacol 1997; 120: 749-56.

37. Sanna E, Murgia A, Casula A, Biggio G. Differential subunit dependence of the actions of the general anesthetics alphaxalone and etomidate at gamma-aminobutyric acid type A receptors expressed in Xenopus laevis oocytes. Mol Pharmacol 1997; 51: 484-90.

38. Belelli D, Lambert JJ, Peters JA, Wafford K, Whiting PJ. The interaction of the general anesthetic etomidate with the gammaaminobutyric acid type A receptor is influenced by a single amino acid. Proc Natl Acad Sci USA 1997; 94: 11031-6.

39. Pistis M, Belelli D, McGurk K, Peters JA, Lambert JJ. Complementary regulation of anaesthetic activation of human (alpha6beta3gamma2L) and Drosophila (RDL) GABA receptors by a single amino acid residue. J Physiol 1999; 515: 3-18.

40. Siegwart $R$, Jurd $R$, Rudolph $U$. Molecular determinants for the action of general anesthetics at recombinant alpha(2)beta(3)gamma(2)gamma-aminobutyric acid(A) receptors. J Neurochem 2002; 80: 140-8.

41. Reynolds DS, Rosahl TW, Cirone J, et al. Sedation and anesthesia mediated by distinct $\mathrm{GABA}(\mathrm{A})$ receptor isoforms. J Neurosci 2003; 23: 8608-17.

42. Cirone J, Rosahl TW, Reynolds DS, et al. Gamma-aminobutyric acid type A receptor beta 2 subunit mediates the hypothermic effect of etomidate in mice. Anesthesiology 2004; 100: 1438-45.

43. Jurd R, Arras $M$, Lambert $S$, et al. General anesthetic actions in vivo strongly attenuated by a point mutation in the GABA(A) receptor beta3 subunit. FASEB J 2003; 17: 250-2.

44. Zeller A, Arras $M$, Lazaris A, Jurd R, Rudolph U. Distinct molecular targets for the central respiratory and cardiac actions of the general anesthetics etomidate and propofol. FASEB J 2005; 19: 1677-9.

45. Fritschy JM, Benke D, Mertens S, Oertel WH, Bachi T, Mohler $H$. Five subtypes of type A gamma-aminobutyric acid receptors identified in neurons by double and triple immunofluorescence staining with subunit-specific antibodies. Proc Natl Acad Sci USA 1992; 89: 6726-30.

46. Zeller A, Arras M, Jurd R, Rudolph U. Identification of a molecular target mediating the general anesthetic actions of pentobarbital. Mol Pharmacol 2007; 71: 852-9.

47. Lambert $S$, Arras $M$, Vogt KE, Rudolph U. Isoflurane-induced surgical tolerance mediated only in part by beta3-containing GABA(A) receptors. Eur J Pharmacol 2005; 516: 23-7.

48. O'Hara PJ, Sheppard PO, Thogersen H, et al. The ligandbinding domain in metabotropic glutamate receptors is related to bacterial periplasmic binding proteins. Neuron 1993; 11: 41-52.

49. Nishikawa K, MacIver MB. Membrane and synaptic actions of halothane on rat hippocampal pyramidal neurons and inhibitory interneurons. J Neurosci 2000; 20: 5915-23.

50. Jevtovic-Todorovic $V$, Todorovic SM, Mennerick S, et al. Nitrous oxide (laughing gas) is an NMDA antagonist, neuroprotectant and neurotoxin. Nat Med 1998; 4: 460-3.
51. Furukawa H, Singh SK, Mancusso R, Gouaux E. Subunit arrangement and function in NMDA receptors. Nature 2005; 438: $185-92$.

52. Mori $H$, Mishina $M$. Structure and function of the NMDA receptor channel. Neuropharmacology 1995; 34: 1219-37.

53. Sucher NJ, Akbarian S, Chi CL, et al. Developmental and regional expression pattern of a novel NMDA receptor-like subunit (NMDAR-L) in the rodent brain. J Neurosci 1995; 15: 6509-20.

54. Franks NP, Lieb WR. A serious target for laughing gas. Nat Med 1998; 4: 383-4.

55. Sato Y, Kobayashi E, Hakamata Y, et al. Chronopharmacological studies of ketamine in normal and NMDA epsilon1 receptor knockout mice. Br J Anaesth 2004; 92: 859-64.

56. Sato Y, Kobayashi E, Murayama T, Mishina M, Seo N. Effect of $\mathrm{N}$-methyl-D-aspartate receptor epsilon1 subunit gene disruption of the action of general anesthetic drugs in mice. Anesthesiology 2005; 102: 557-61.

57. Borges $K$, Dingledine $R$. AMPA receptors: molecular and functional diversity. Prog Brain Res 1998; 116: 153-70.

58. Joo DT, Xiong Z, MacDonald JF, et al. Blockade of glutamate receptors and barbiturate anesthesia: increased sensitivity to pentobarbital-induced anesthesia despite reduced inhibition of AMPA receptors in GluR2 null mutant mice. Anesthesiology 1999; 91: 1329-41.

59. Joo DT, Gong D, Sonner JM, et al. Blockade of AMPA receptors and volatile anesthetics: reduced anesthetic requirements in GluR2 null mutant mice for loss of the righting reflex and antinociception but not minimum alveolar concentration. Anesthesiology 2001; 94: 478-88.

60. Heurteaux C, Guy N, Laigle C, et al. TREK-1, a K+ channel involved in neuroprotection and general anesthesia. EMBO J 2004; 23: 2684-95.

61. Linden AM, Aller MI, Leppa E, et al. The in vivo contributions of TASK-1-containing channels to the actions of inhalation anesthetics, the alpha(2) adrenergic sedative dexmedetomidine, and cannabinoid agonists. J Pharmacol Exp Ther 2006; 317: 615-26.

62. Linden AM, Sandu C, Aller MI, et al. TASK-3 knockout mice exhibit exaggerated nocturnal activity, impairments in cognitive functions, and reduced sensitivity to inhalation anesthetics. J Pharmacol Exp Ther 2007; 323: 924-34.

63. Matta JA, Cornett PM, Miyares RL, Abe K, Sahibzada N, Ahern $G P$. General anesthetics activate a nociceptive ion channel to enhance pain and inflammation. Proc Natl Acad Sci USA 2008; 105: 8784-9.

64. Hentschke H, Schwarz C, Antkowiak B. Neocortex is the major target of sedative concentrations of volatile anaesthetics: strong depression of firing rates and increase of GABAA receptormediated inhibition. Eur J Neurosci 2005; 21: 93-102.

65. Pirker S, Schwarzer C, Wieselthaler A, Sieghart W, Sperk G. GABA(A) receptors: immunocytochemical distribution of 13 subunits in the adult rat brain. Neuroscience 2000; 101: 815-50.

66. Antognini JF, Schwartz K. Exaggerated anesthetic requirements in the preferentially anesthetized brain. Anesthesiology 1993; 79: 1244-9.

67. Rampil IJ, Mason P, Singh H. Anesthetic potency (MAC) is independent of forebrain structures in the rat. Anesthesiology 1993; 78: 707-12.

68. Kim J, Yao A, Atherley R, Carsten E, Jinks SL, Antognini JF. Neurons in the ventral spinal cord are more depressed by isoflurane, halothane, and propofol than are neurons in the dorsal spinal cord. Anesth Analg 2007; 105: 1020-6.

69. Jinks SL, Bravo M, Hayes SG. Volatile anesthetic effects on midbrain-elicited locomotion suggest that the locomotor network in the ventral spinal cord is the primary site for immobility. Anesthesiology 2008; 108: 1016-24. 
70. Alvarez FJ, Taylor-Blake B, Fyffe RE, De Blas AL, Light AR. Distribution of immunoreactivity for the beta 2 and beta 3 subunits of the $\mathrm{GABA}_{\mathrm{A}}$ receptor in the mammalian spinal cord. J Comp Neurol 1996; 365: 392-412.

71. Gahwiler BH. Organotypic monolayer cultures of nervous tissue. J Neurosci Methods 1981; 4: 329-42.

72. Gahwiler BH, Capogna M, Debanne D, McKinney RA, Thompson SM. Organotypic slice cultures: a technique has come of age. Trends Neurosci 1997; 20: 471-7.

73. Christie $S B$, De Blas AL. GABAergic and glutamatergic axons innervate the axon initial segment and organize GABA(A) receptor clusters of cultured hippocampal pyramidal cells. J Comp Neurol 2003; 456: 361-74.

74. Brunig I, Scotti E, Sidler C, Fritschy JM. Intact sorting, targeting, and clustering of gamma-aminobutyric acid A receptor subtypes in hippocampal neurons in vitro. J Comp Neurol 2002; 443: 43-55.

75. Di Cristo $G, W u$ C, Chattopadhyaya B, et al. Subcellular domain-restricted GABAergic innervation in primary visual cortex in the absence of sensory and thalamic inputs. Nat Neurosci 2004; 7: 1184-6.

76. Gredell JA, Turnquist PA, Maciver MB, Pearce RA. Determination of diffusion and partition coefficients of propofol in rat brain tissue: implications for studies of drug action in vitro. Br $\mathrm{J}$ Anaesth 2004; 93: 810-7.

77. Benkwitz C, Liao M, Laster MJ, Sonner JM, Eger EI 2nd, Pearce $R A$. Determination of the $\mathrm{EC}_{50}$ amnesic concentration of etomidate and its diffusion profile in brain tissue: implications for in vitro studies. Anesthesiology 2007; 106: 114-23.

78. Antkowiak B. In vitro networks: cortical mechanisms of anaesthetic action. Br J Anaesth 2002; 89: 102-11.

79. Caplan JB, Madsen JR, Schulze-Bonhage A, AschenbrennerScheibe R, Newman EL, Kahana MJ. Human theta oscillations related to sensorimotor integration and spatial learning. J Neurosci 2003; 23: 4726-36.

80. Blatow M, Rozov A, Katona I, et al. A novel network of multipolar bursting interneurons generates theta frequency oscillations in neocortex. Neuron 2003; 38: 805-17.

81. Drexler B, Roether $C L$, Jurd R, Rudolph $U$, Antkowiak B. Opposing actions of etomidate on cortical theta oscillations are mediated by different gamma-aminobutyric acid type A receptor subtypes. Anesthesiology 2005; 102: 346-52.

82. Morgan M, Lumley J, Whitwam JG. Etomidate, a new watersoluble non-barbiturate intravenous induction agent. Lancet 1975; 1: 955-6.

83. Avramov MN, Husain MM, White PF. The comparative effects of methohexital, propofol, and etomidate for electroconvulsive therapy. Anesth Analg 1995; 81: 596-602.

84. Gazdag G, Kocsis N, Tolna J, Ivanyi Z. Etomidate versus propofol for electroconvulsive therapy in patients with schizophrenia. J ECT 2004; 20: 225-9.

85. Banoub M, Tetzlaff JE, Schubert A. Pharmacologic and physiologic influences affecting sensory evoked potentials: implications for perioperative monitoring. Anesthesiology 2003; 99: 716-37.

86. Sloan TB. Anesthetic effects on electrophysiologic recordings. J Clin Neurophysiol 1998; 15: 217-26.

87. Drexler B, Jurd R, Rudolph U, Antkowiak B. Distinct actions of etomidate and propofol at beta3-containing gamma-aminobutyric acid type A receptors. Neuropharmacology 2009; 57: 446-55.

88. Jia F, Yue M, Chandra D, Homanics GE, Goldstein PA, Harrison $N L$. Isoflurane is a potent modulator of extrasynaptic GABA(A) receptors in the thalamus. J Pharmacol Exp Ther 2008; 324: 1127-35.

89. Ying SW, Werner DF, Homanics GE, Harrison NL, Goldstein $P A$. Isoflurane modulates excitability in the mouse thalamus via GABA-dependent and GABA-independent mechanisms. Neuropharmacology 2009; 56: 438-47.

90. Nelson LE, Guo TZ, Lu J, Saper CB, Franks NP, Maze M. The sedative component of anesthesia is mediated by GABA(A) receptors in an endogenous sleep pathway. Nat Neurosci 2002; 5: 979-84.

91. Zecharia AY, Nelson LE, Gent TC, et al. The involvement of hypothalamic sleep pathways in general anesthesia: testing the hypothesis using the $\mathrm{GABA}_{\mathrm{A}}$ receptor beta3N265M knock-in mouse. J Neurosci 2009; 29: 2177-87.

92. Grasshoff $C$, Jurd R, Rudolph U, Antkowiak B. Modulation of presynaptic beta3-containing GABAA receptors limits the immobilizing actions of GABAergic anesthetics. Mol Pharmacol 2007; 72: 780-7.

93. Grasshoff C, Antkowiak B. Organotypic cultures of spinal cord ventral horn are valuable tools for investigating immobilityrelated mechanisms in vitro. Anesth Analg 110: 638.

94. Banks MI, Pearce RA. Dual actions of volatile anesthetics on GABA(A) IPSCs: dissociation of blocking and prolonging effects. Anesthesiology 1999; 90: 120-34.

95. Drexler B, Jurd R, Rudolph U, Antkowiak B. Dual actions of enflurane on postsynaptic currents abolished by the gammaaminobutyric acid type A receptor beta3(N265M) point mutation. Anesthesiology 2006; 105: 297-304.

96. Li GD, Chiara DC, Cohen JB, Olsen RW. Numerous classes of general anesthetics inhibit etomidate binding to gamma-aminobutyric acid type A $\left(\mathrm{GABA}_{\mathrm{A}}\right)$ receptors. J Biol Chem 2010; 285 : 8615-20.

97. Drexler B, Grasshoff C, Rudolph U, Unertl K, Antkowiak B. The GABA(A) receptor family: possibilities for the development of better anesthetics (German). Anaesthesist 2006; 55: 287-95.

98. Korpi ER, Grunder G, Luddens H. Drug interactions at GABA(A) receptors. Prog Neurobiol 2002; 67: 113-59.

99. Heldt SA, Ressler KJ. Forebrain and midbrain distribution of major benzodiazepine-sensitive $\mathrm{GABA}_{\mathrm{A}}$ receptor subunits in the adult C57 mouse as assessed with in situ hybridization. Neuroscience 2007; 150: 370-85.

100. Olsen $R W$, Sieghart $W$. GABA A receptors: subtypes provide diversity of function and pharmacology. Neuropharmacology 2009; 56: 141-8. 